\section{Some contributions of philosophy to education ${ }^{1}$}

\begin{abstract}
¿Para Qué sirve la filosofía de la educación? ¿Cuál es la CONTRIBUCIÓN DE LAS FINALIDADES, HABILIDADES Y ACTITUDES FILOSÓfICAS A LA PRÁCTICA EDUCATIVA? ¿QUÉ SE PUEDE LOGRAR? EN ESTE ARTÍCULO, NO SE PRETENDE CONSIDERAR NINGUNA DOCTRINA FILOSÓFICA EN PARTICULAR. TAMPOCO SE TRATA DE EXAMINAR LAS IMPLICACIONES EDUCATIVAS DE UNO U OTRO PUNTO DE VISTA FILOSÓFICO. EN VEZ DE ESO, LA REFLEXIÓN ESTÁ DIRIGIDA A LA ACTIVIDAD FILOSÓfICA EN Sí MISMA. POR TANTO, LAS PREgUNTAS SON MÁS BIEN GENERALES Y CIERTAMENTE NO SON NUEVAS. SIN EMBARGO, ESTAS PREGUNTAS ADQUIEREN UN ESPECIAL RELIEVE DESDE LA PERSPECTIVA DE LAS TENDENCIAS ACTUALES, QUE PROBABLEMENTE TENDRÁN UNA CRECIENTE INFLUENCIA EN LAS FUTURAS CIRCUNSTANCIAS DE NUESTRA VIDA Y EN NUESTRAS CONCEPCIONES OPERATIVAS DE LA EDUCACIÓN.
\end{abstract}

PALABRAS CLAVE: CAMBIOS TECNOLÓGICOS, OBJETIVOS EDUCATIVOS, VALOR DE LA FILOSOFÍA, ENFOQUE INTERDISCIPLINAR.

OF WHAT USE IS PHILOSOPHY TO EDUCATION? WHAT DO PHILOSOPHICAL PURPOSES, SKILLS AND ATTITUDES BRING TO EDUCATIONAL PRACTICE? WHAT MIGHT THEY ACCOMPLISH? MY CONCERN IN WHAT FOLLOWS IS NOT WITH ANY PARTICULAR SET OF PHILOSOPHICAL DOCTRINES, NOR AM I INQUIRING AFTER THE EDUCATIONAL IMPLICATIONS OF THIS OR THAT PHILOSOPHICAL VIEWPOINT. RATHER, MY QUESTIONS PERTAIN TO PHILOSOPHICAL ACTIVITY ITSELF. THE QUESTIONS ARE THUS QUITE GENERAL AND THEY ARE CERTAINLY NOT NEW. BUT THEY TAKE ON SPECIAL URGENCY WHEN VIEWED IN THE PERSPECTIVE OF CURRENT TRENDS THAT ARE LIKELY INCREASINGLY TO AFFECT OUR FUTURE CIRCUMSTANCES OF LIFE AND OUR OPERATIVE CONCEPTIONS OF EDUCATION.

KEYWORDS: TECHNOLOGICAL CHANGE, EDUCATIONAL AIMS, VALUE OF PHILOSOPHY, INTER-DISCIPLINARY APPROACH.

1 Session of the $20^{\text {in }}$ World Congress of Philosophy in Boston. August 1998. Se publicó parcialmente en las Actas del Congreso.

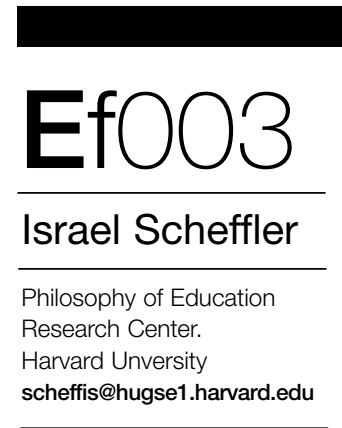

Harvard Unversity

scheffis@hugse1.harvard.edu 


\section{No3 ESE 94 I. CURRENT TRENDS}

What are these trends? We have been living through a period that has estudios seen a remarkable burst of technological energy which has already ISRAEL SCHEFFLer transformed, and, will continue to transform a wide variety of human activities, including education, in ways that can hardly be foreseen. Advances in the underlying special sciences have, concomitantly, proceeded apace, spawning a welter of new technical conceptualizations in the physical, biological, social, and professional fields, and challenging our prior assumptions concerning life and death, morality and society.

Modes of transportation, communication, and interaction in every sphere have been radically accelerated, with the result that our globe has shrunk in physical size while cultural distances have, ironically, often widened and become more opaque to mutual understanding. And while the sciences and the global technical culture they have made possible base themselves on appeal to stringent empirical tests, open theoretical debate, and objective criteria of evidence, large segments of our public have increasingly rejected the very notions of objective inquiry and the pursuit of truth, replacing them with the idea that subjectivism rules and (almost) anything goes. Clearly, there is work for philosophy to do in responding to our new intellectual and cultural situation. I shall here outline some types of philosophical work that seem to me pressing under present circumstances and of particular importance in and for education.

\section{THE RATIONALE OF SCIENTIFIC INQUIRY}

First, I consider the task of developing a broad intellectual approach to the advancing scientific specializations that surround us on all sides. These specializations pose difficult challenges to the understanding when they are seen either as self-enclosed authorities embodying indubitable truths or else as arbitrary forms of social self-expression. What is urgently needed, by students and public alike, is an insight into the rationale of scientific inquiry-a grasp of the basic logic animating the provisional conclusions of the special sciences. These conclusions need to be understood, explicated, and related to the methods of inquiry by which they are developed and evaluated. The more such specializations impinge on public policy, the more urgent it is to make the rationale of their deliverances as well as their limitations understandable to a broad public, beginning, first of all, with the students in our schools. The desired aim in this context is to present science not as primarily an engine of technology, but rather, and above all, as a dynamic form of self-critical thought powered by the imagination yet answerable to the demands of logic and credible evidence.

This requires not only that the special idioms of scientific specialties be interpreted in terms accessible to the layman, to whatever extent this is possible, but also that the structures of their reasoning be grasped-that their assertions be viewed not as isolated and inert facts but as provisional judgments arising out of a creative search for explanatory theories, tempered by an empirical assessment of their adequacy. In turn, this requires that basic curricula in the schools be designed accordingly, so as to interpret their specialized materials to the novice rather than presenting them as fixed and final. Understood in the context of scientific reasoning, such materials are to be seen as bounded by the methodology supplying whatever authority they can claim.

In this curricular task, thinkers concerned with the history and philosophy of science have the capability to contribute significantly, both in explicating technical concepts and in setting forth the 
inferential patterns motivating the data of specialized investigations. Such thinkers may thus assist in overcoming the narrow treatment of subject matter, and help in exhibiting such matter as neither dogmatic nor arbitrary but rather as exemplifying principles of critical thought.

\section{Practice and disciplinary variety}

When we turn from understanding the data of particular specializations to the question of understanding their applications to practice or policy, we confront additional problems ${ }^{2}$. For such applications do not flow directly from given scientific disciplines taken one at a time. When the findings of a special discipline are to be brought to bear on practice, they need to be conjoined with other special findings, since practical problems are never exhaustively solvable by the single discipline. Thus, it is not only the internal rationale of any given scientific specialization that needs to be grasped but also its conjoint bearing, along with other relevant specializations, on practical problems of interest. Each specialization to be acquired by our students is to be presented not only in terms of its internal disciplinary context, but also with reference to its foreign relations, that is, the points of potential contact between it and other special studies.

The disciplines are, in effect, to be taught to our students not only linearly but also as ranged around the common practical problems to which they may be applied as relevant groups. Since the members of these groups are typically organized by different concepts and interests, the learner must, if he is to apply his learning to practice, acquire the ability to step outside the bounds of the discipline which may be most familiar to him. He cannot retire into the core of this discipline and stay there; he needs to hear the voices of those without who speak in foreign tongues, and needs also to make him self understood to those who dwell beyond. A sensitivity to the languages and procedures of diverse inquiries is required, along with the willingness to hear others who have been differently trained. Further, the learner needs an ability to use disparate disciplines jointly in attacking practical problems, linking them, where possible, through translation or partial translation and - beyond the reach of translation altogether-an ability to assign the items of varying specializations to different segments of the practical problems in question ${ }^{3}$.

In fostering the requisite sensitivity to linguistic and procedural variation, philosophy has another important contribution to make. For philosophers are professionally disposed to deal with a plurality of subject matters and a variety of languages, seeing the commonalties as well as the, differences between them, translating back and forth where possible and putting relevant varieties together in application to problems. Trained in the history of thought, philosophers are committed to making sense of diverse abstruse systems, and committed also to seeing how such systems relate to one another, how they may be intertranslatable and how they may, on the contrary, repel one another in content, style, or procedure. Such predispositions are of inestimable value in curricular formation and in teaching not just for disciplinary understanding but also for disciplinary application to practice and policy.

\footnotetext{
${ }^{2}$ For my defence of the ideal of objectivity in science, see Scheffler, 1982.

${ }^{3}$ For the application of scientific disciplines to practice, see chapter IV "The Education of Policy Makers" of Scheffler, 1985
} 


\section{N03 ESE 96}

ESTUDIOS

ISRAEL SCHEFFLER

\section{Appreciation and human understanding}

We have so far spoken of enhancing the understanding of specialized data by placing them within a context of logical structure and relevant methodological constraint. In dealing with applications to practice and policy, we have, further, emphasized the need for avoiding tunnel vision in order to profit from the various specializations bearing on practical solutions.

In both of these respects, philosophy has much to offer. But this is not all.

The application of special scientific studies to practical problems goes beyond disciplinary specializations altogether. For "the awareness of such problems is not the monopoly of any special discipline nor is it the exclusive province of any set of disciplines. Pooling the specialized perspectives of the several forms of inquiry does not yet guarantee human understanding" (Scheffler, 1985) that is, comprehension of the human problems on which such perspectives are brought to bear.

Applications affect the activities, values, thoughts and feelings of various people and these require to be taken into account in evaluating the applications in question. Taking them into account means that we understand what people say when they describe their circumstances and express their opinions, their fears and their hopes. It means that we have access to the way affected persons understand themselves and define their situations, that "we hear what they say when they speak in their own voice" (Scheffler, 1985). Here what is required is not just the sensitivity to language that we have described as a philosophical virtue, but also the willingness to listen genuinely, to enter sympathetically into the thought worlds of others, as expressed not in the locutions of any specialized inquiry, but the informal, and often idiosyncratic expressions of everyday life, colored by personal habit and predilection. The philosopher, trained to enter into the systematic worlds of radically diverse thinkers, to attempt to gauge their circumstances, motivations and expressions-in short, to reconstruct their thought sympathetically, has a vital contribution to make to the formation of pupils, who will be applying, as well as absorbing, the data of specialized studies in the whole of their future lives.

\section{Application and value}

Application to practice involves choice. It is not enough to have the requisite knowledge to realize a variety of alternatives for dealing with a practical problem. Nor is it enough to know how each alternative will impinge on the lives of those it affects. To choose an alternative for realization is an expression of: preference, a conferring of value upon such alternative, which creates a precedent, thus, in effect, creating a presumptive principle of action. R. M. Hare has emphasized the fact that decisions are the germs of principles which reverberate into other cases without limit (Hare, 1952, pp. 56-78). Awareness of the incipient principles one is thus expressing in application is awareness of one's actual values, and facilitates their critical review.

A critical self-consciousness respecting one's values is a primary aim of education. It is one that is particularly urgent in a time of rapid technological change, when its momentum threatens to sweep all before it, overwhelming both moral scruple and human feeling. To attain this educational aim it is essential to, be able to discourse about values, to navigate fearlessly in the conceptual areas where factual and value considerations intermingle. To avoid blindness in action, it is essential to grapple 
with the task of formulating a code of moral principle by which one may act reflectively. Here, philosophy is of inestimable assistance, for unlike modern dispositions to avoid value discussions altogether or to consider values beyond rational treatment, philosophy embodies a tradition of over two millennia in which value considerations are treated seriously, subtly and comprehensively. To build elements of this tradition into educational curricula is an important contribution of philosophy to, an educational future of ethical substance.

\section{ESE N³ 2002}

\section{ESTUDIOS}

SOME CONTRIBUTIONS

OF PHILOSOPHY TO

EDUCATION

\section{The PAST AND THE PRESENT}

The mention of the long tradition of philosophical discussion raises for consideration another important benefit that philosophy renders to education. This benefit lies in the very fact that philosophical discussion inevitably recalls its past. Unlike scientific and mathematical training, which move ever onward, leaving past developments behind, philosophical study never outgrows its past, recalling earlier thinkers and arguments even as it forges ahead. Placing the intellectual, literary, and moral contents of school curricula in the context of a long history of relevant treatments, philosophy thus breaks the tenacious hold of the present upon the consciousness of modern youth.

The present is of course the scene of all activity to be undertaken by our pupils and must therefore retain its centrality for their deliberations. Yet, untempered by memory, a focus on the present is a source of blindness, eliminating the funded experience of our predecessors from consideration as a resource for current understanding and perception. Strengthened by the momentum of technological advance which looks ever toward the potential transformation of prevailing arrangements by new devices and never looks back, the present-centeredness of much contemporary schooling runs the risk of distorting educational values by its cultural amnesia.

A current example is the impact of the computer on educational thinking. The computer is, of course, the agent of vast changes in social arrangements in recent years, and technical concepts of information and algorithm are its intellectual underpinnings. Opportunities for increased efficiency in teaching and enhanced individualization of learning are but two promises of computer applications that prudent educators need to explore. But the basic hazard educators need to confront is a narrowing of their educational vision-a reduction of their fundamental concepts to presumed technological correlates. It is in helping to overcome this hazard that philosophy may now serve education as an important resource ${ }^{4}$.

Traditional epistemology, to take one central instance, views knowledge -even in its purely propositional form, as distinct from know-how or skill- in the broad contexts of truth, evidence, and belief. Knowledge, it insists, cannot be reduced to information alone, in the technical sense, i.e. to bits of bare propositional content. An item of knowledge, to qualify as such, must also be true. Education, insofar as it concerns knowledge, must therefore rest on an appeal to truth, assessing the truth-value of available content, and referring implicitly to operative standards of truth. 
2002 No3 ESE 98 Nor, as epistemology shows, can knowledge be presumed to depend solely on algorithm. A claim to knowledge bears reference to evidence but such evidence in general comprises good reasons in support of a conclusion rather than only algorithms or decision procedures, or even proofs. Even where proof is indeed available, it is important to note that, whereas it is subject to check by routine process, it cannot be discovered by routine process. The generation of proofs is a creative rather than an algorithmic outcome of inquiry, a matter of heuristics, ingenuity and luck rather than mechanical routine.

Finally, knowledge is, for epistemology, no merely impersonal unit of propositional content, even if true and, moreover, grounded in adequate evidence. For such content is always formulated in the concepts of a historical language and it is embodied in belief, evidenced not only in assertions but also in actions and purposes. To assess a claim to knowledge thus involves inquiry into concepts channeling relevant beliefs as well as the purposes expressed in related conduct. To view knowledge not as an inert corpus of informational items to be manipulated by algorithm, but rather as a domain of human belief aspiring to truth, advancing through creative discovery and evidenced in statement, action and purpose is thus the perspective that the heritage of philosophy lends to educational practice (Scheffler, 1965).

\section{INFORMATION AND EDUCATIONAL AIMS}

When we move beyond the educational aim of enhancing knowledge to consider educational aims in general, we find the popular computer concept of information to be clearly inadequate.

"The everyday notion of information refers to material we can understand and interpret in context. Grasping what it expresses, we can paraphrase it and evaluate its contextual relevance, criticize and reject it or back it up appropriately, respond to it with feeling, sense its metaphorical echoes, appraise its bearing on our purposes, and apply it in our activity. The computer itself cannot be properly described as doing any of these things, in the everyday senses of the terms involved. To characterize the electronic state of computer circuitry in terms of information is to employ the word under a different interpretation. Further to construe the mind in terms of "computer information" empties the human notion of virtually all its content” (Scheffler, 1991, p. 91).

Even the full-blooded human sense of information is incapable of expressing all our educational aims with respect to knowledge. As Ryle has put it, knowing a fact requires "having taken it in, i.e., being able and ready to operate with it, from it, around it and upon it. To possess a piece of information is to be able to mobilize it apart from, its rote-neighbors and out of its rote-formulation in unhackneyed and ad hoc tasks" (Ryle, 1967, p. 111). And learning, even in the context of problemsolving, goes well beyond information, in any sense. For it does not simply acquire information but "entertains suppositions, rejects the accepted, conceives the possible, elaborates the doubtful or false, questions the familiar, guesses at the imaginable, improvises the unheard of. An intelligence capable only of storing and applying bits of information would be profoundly incapacitated for the solving of problems" (Scheffler, 1991, p. 93).

Beyond the language of information altogether are those traditional educational formulations that speak of insight, skill, and norm. The first of these, i.e. insight, describes educational aims in terms of 
perception, vision and illumination, intuition of nuance and pattern, imaginative grasp of overtone and undertone. The second, i.e. skill, discusses aims in terms of the forming or strengthening of abilities, the know-how commanded by a person rather than the know-that, the capability to deal with the tasks and challenges in every domain of life. The last of the three formulations focuses on norms rather than either information or capacities, on the tendencies and dispositions of a person, on what he does do rather than what he can do. Here again, we have left the notion of information behind. For we are dealing here not with what people believe nor with what they are equipped to do, but with their character, what they can reliably be expected to do with their predictable patterns of conduct, taste, and emotion.

These various realms of educational aims all need to be kept steadfastly in view as we make progress on any educational front.

The whole array of ends embodied in the traditional locutions we have described must serve as the context within which we gauge our educational situation. Rather than cutting this array down to the size of our technology, we should strive to look beyond our technology, to determine the future purposes and directions of our further efforts. And in this task, philosophy serves a vital function by keeping the broadest conceptions of human learning in view as we move into a new and uncharted technological future.

\section{ESE №3 2002}

\section{ESTUDIOS}

SOME CONTRIBUTIONS

OF PHILOSOPHY TO

EDUCATION 


\section{2 №3 ESE IOO BIBLIOGRAFÍA}

ESTUDIOS

ISRAEL SCHEFF

- Hare, R.M. (1952). The Language of Morals. Oxford: Clarendon Press, 1952.

Ryle, G. (1967). Teaching and Trainingll. En R. S. Peters (Ed.), The Concept of Education London: Routledge and Kegan Paul.

Scheffler, I. (1965). Conditions of Knowledge. Chicago: The University of Chicago Press.

Scheffler, I. (1982). Science and Subjectivity (2a ed.). Indianapolis, Indiana: Hackett.

- Scheffler, I. (1985). Of Human Potential. London: Routledge and Kegan Paul, (esp. p. 100 ff.).

Scheffler, I. (1991). In Praise of the Cognitive Emotions. New York: Routledge, Chapman and Hall. 